\title{
EVALUATION OF N ADDITIVES FOR IMPROVING N USE EFFICIENCY OF SURFACE APPLIED UREA TO DRY SEEDED AND PERMANENTLY FLOODED RICE
}

\author{
${ }^{1}$ David D. Dunn and ${ }^{2}$ Pawel Wiatrak \\ ${ }^{1}$ Rice Specialist, University of Missouri, Delta Center, Portageville, Missouri, USA \\ ${ }^{2}$ School of Agricultural, Forest and Environmental Sciences, Clemson University, Edisto REC, Blackville, USA
}

Received 2014-05-26; Revised 2014-06-09; Accepted 2014-06-21

\begin{abstract}
There are several potential Nitrogen $(\mathrm{N})$ loss mechanisms in a dry seeded and delayed flood system rice (Oryza Satvia L.) production system including urea volatilization and denitrification. The scope and magnitude of these potential losses are largely weather dependent. Two additives (stabilizers), Agrotain and Nutrisphere-N, have been offered to rice producers for controlling these potential losses. This study compared these two products in their ability to maintain rice grain yields, where cultural management maximizes these loss mechanisms. Response of rice to urea-N stabilizers varied in 2007 and 2008 depending on soil and environmental conditions. In 2007, dry soil surface at time of urea-N application and lack of rainfall resulted in a low loss due to $\mathrm{N}$ volatilization. However, urea- $\mathrm{N}$ volatilization or denitrification were higher in 2008 and using Agrotain stabilizer resulted in higher yields of rice at $78 \mathrm{~kg} \mathrm{~N} \mathrm{ha}^{-1}$. Across years, Agrotain and Nutrisphere-N were similar in terms of slightly improving rice grain yields compared to untreated urea at the rate of $78 \mathrm{~kg} \mathrm{~N} \mathrm{ha}^{-1}$. Therefore, urea stabilizers may offer a good solution in years with high potential for urea-N losses.
\end{abstract}

Keywords: Rice, Nutrisphere-N, Phosphorus

\section{INTRODUCTION}

Rice is an important cereal crop in the Mississippi Alluvial Delta Region, USA. In this area, the most common rice production system is based on dry seeded and delayed flood system. Proper nitrogen nutrition is critical for producing maximum rice grain yields and supplemental Nitrogen $(\mathrm{N})$ fertilizer must be supplied to achieve high yields. Urea is a dominant $\mathrm{N}$ fertilizer used by producers who establish and maintain a permanent flood during the majority of the rice production season. A standard rice $\mathrm{N}$ fertilization rate for the North Mississippi River Delta area is 78 to $134 \mathrm{~kg} \mathrm{~N} \mathrm{ha}^{-1}$ as urea applied pre-flood at first tiller followed by an aerial application of $34 \mathrm{~kg} \mathrm{~N} \mathrm{ha}^{-1}$ at the $1.3 \mathrm{~cm}$ inter-node Corresponding Author: David D. Dunn, Rice Specialist, University of Missouri, Delta Center, Portageville, Missouri, USA

elongation stage of development and an additional $34 \mathrm{~kg}$ $\mathrm{N}$ ha ${ }^{-1}$ applied one week later (Dunn and Stevens, 2006). Managing $\mathrm{N}$ fertilization in dry-seeded and delayed flood rice production systems can be challenging due to potential $\mathrm{N}$ losses. The potential $\mathrm{N}$ loss pathways include urea- $\mathrm{N}$ volatilization before flooding and denitrification after flooding.

Surface applications of urea are not subject to potential volatilization loss until it is hydrolyzed to ammonium $\left(\mathrm{NH}_{4}{ }^{+}\right)$via a reaction catalyzed by the urease enzyme (He et al., 1999). This reaction results in soil $\mathrm{pH}$ increase in the immediate vicinity of the urea. If the soil $\mathrm{pH}$ increases above 7.0 as urea is hydrolyzed, formation of ammonia gas is favored, as opposed to ammonium-N, which may result in some $\mathrm{N}$ lost to the atmosphere if 
urea is on the soil surface. This potential $\mathrm{N}$ volatilization loss is enhanced with increased soil temperature. However, conversion of urea-N to ammonium $\mathrm{N}$ occurs only if the urea is dissolved in soil water and in presence of the urease enzyme. As a result, little or no $\mathrm{N}$ volatilization loss occurs when surface applied urea is applied to dry soil or incorporated into the soil with tillage, rainfall or irrigation.

To minimize the potential for $\mathrm{N}$ volatilization loss from dry seeded and delayed flood rice production systems, traditionally recommended fertility program includes application of urea to dry soil just prior to establishing a permanent flood. This limits the length of time that the urea is exposed on the soil surface prior to movement of the urea below the soil surface with the permanent flood irrigation. However, depending on well pump capacity and land area, fields often take several days to fully flood after urea is broadcast applied. In extreme cases, one week to 10 days may elapse before permanent flood is established.

The unpredictability of weather during this critical time has spurred development and use of urea stabilizer products which are intended to reduce the potential for urea-N volatilization and/or slow the nitrification process. There are currently several urea stabilizers commercially available to rice producers. The most commonly available stabilizer, N-(n-butyl) thiophosphoric Triamide (NBPT), is a urease inhibitor marketed as Agrotain (AI, 2012). Nutrisphere-N, maleicitaconic copolymer, is marketed as effective in slowing urea hydrolysis and nitrification process (SFP, 2012).

The objective of these studies was to compare the effectiveness of two commercially available $\mathrm{N}$ stabilizers Agrotain and Nutrisphere- $\mathrm{N}$ on grain yields in a dry seeded and delayed flood rice production system under varying soil and climatic conditions.

\section{MATERIALS AND METHODS}

\subsection{Site Preparation and Management}

In order to evaluate two fertilizer $\mathrm{N}$ stabilizers for rice production, a total of four individual experiments were conducted at two locations in 2007 and 2008. Location A was near Glennonville, Missouri on a Dewitt silt loam soil (fine, smectitic, thermic, Typic, Albaqualf) overlaying a thick silty clay loam argillic horizon. Location B was located near Portageville, Missouri on a Sharkey clay soil (very-fine, smectitic, thermic Chromic Epiaquert). Plots were shifted to a different experimental area at each location for the second year in order to maintain a soybean-rice rotation. Soil samples were collected from each location prior to establishing studies. Soil test results indicated that the fertility status of each location was adequate for rice production according to the University of Missouri soil test interpretations.

Cultivar 'Wells' rice was drill seeded in $19 \mathrm{~cm}$ row spacing at seeding rate of $84 \mathrm{~kg} \mathrm{ha}^{-1}$. Since these experiments were planned to maximize the potential for urea-N volatilization loss and denitrification, it was our intent to apply pre-flood urea to wet soils 7 to 10 days before permanent flood establishment when no rain was predicted during the interim. No additional $\mathrm{N}$ was applied at mid-season.

In practice, pre-flood $\mathrm{N}$ treatments of urea, urea plus Agrotain (4.2 $1 \mathrm{Mg}^{-1}$ urea) and Nutrisphere-N (2.1 1 $\mathrm{Mg}^{-1}$ ) at rates of 78,118 and $157 \mathrm{~kg} \mathrm{~N} \mathrm{ha}^{-1}$ were applied 7 to 11 days before flooding at V-4 to V-5 growth stage depending on existing field conditions shown in Table $\mathbf{1}$.

Rice was harvested with a plot combine. Grain was collected from $1.5 \mathrm{~m}$ wide by $7.6 \mathrm{~m}$ long areas of each plot. Yields were adjusted to $13 \%$ grain moisture content.

\subsection{Weather Data}

Weather data was continuously collected at each location via a weather station maintained by the University of Missouri Extension Commercial Agriculture Program. Cumulative precipitation for the three days, immediately prior to urea application, length of time from urea application to permanent flood establishment and cumulative rainfall after urea application, but before permanent flood establishment are summarized for each study in Table 1.

\subsection{Statistical Analysis}

A complete factorial, randomized complete block design with four replications was used for each study. An Analysis of Variance (ANOVA) of the data was performed and pairwise treatment comparisons made with the Least Significant Difference (LSD) procedure (SASI, 1997). The measured level of significance ( $p>F)$ from the ANOVA is presented with the data while LSD values were determined at the 0.10 level of significance. Reporting the actual probability level of measured differences allows for more complete interpretation of the data as opposed to arbitrarily setting a probability level for the studies. 
David D. Dunn and Pawel Wiatrak / American Journal of Agricultural and Biological Sciences 9 (3): 401-406, 2014

Table 1. Rainfall and permanent flood dates relative to nitrogen $(\mathrm{N})$ fertilizer application date at two locations in 2007 and 2008

\begin{tabular}{lcr}
\hline & Year & 2008 \\
\hline Location & 2007 & 0.66 \\
Cumulative precipitation 3 days prior to N application (mm) & & 0.0 \\
A-Glennonville, Missouri & 0.0 & 1.10 \\
B-Portageville, Missouri & & 8.00 \\
Days from application to flood & 11.0 & 10.00 \\
A-Glennonville, Missouri & 7.0 & 1.00 \\
B-Portageville, Missouri & & 0.00 \\
Cumulative precipitation from N application to flood (mm) & 16.8 & 7.1 \\
A-Glennonville, Missouri & & \\
B-Portageville, Missouri & & \\
\hline
\end{tabular}

\section{RESULTS}

An ANOVA summary of rice yield data combined for all four individual studies is presented in Table 2. Highly significant differences in rice yield were measured in the combined data set. Crop year, location, $\mathrm{N}$ stabilizer and $\mathrm{N}$ rate main effects indicated highly significant differences in rice yield. Differences in yield between the two years may reflect more favorable rice production weather conditions in 2007.

If only the main effects of the combined data from both locations and both years of these studies are evaluated, there would seem to be no yield benefit due to the inclusion of either $\mathrm{N}$ stabilizer product. However, numerous highly significant and complex interactions among crop year, location, $\mathrm{N}$ rate and inclusion of $\mathrm{N}$ stabilizers were identified (Table 2). As a result, it was necessary to evaluate the effects of $\mathrm{N}$ stabilizer and $\mathrm{N}$ rate for each study individually. This was not unexpected since the potential for $\mathrm{N}$ loss via volatilization or denitrification differs year-to-year and location-tolocation with varying soil and environmental conditions.

Rice yield results for each individual study are presented in Table 3. Highly significant treatment effects were measured at each location during both years, but specific responses varied for each year. Since there were no significant interactions between $\mathrm{N}$ rate and $\mathrm{N}$ stabilizers for any individual study, only the main effects of $\mathrm{N}$ rate and $\mathrm{N}$ stabilizers were addressed.

Highly significant responses to $\mathrm{N}$ rate were measured at both locations in 2007 and location A in 2008. The response to $\mathrm{N}$ rate at location B in 2008 was significant at the 0.19 probability level. Markedly different soil and environmental conditions existed during the time frame from urea application through permanent flood application in 2008 as compared to 2007. For both years, ambient air temperatures of greater than $26^{\circ} \mathrm{C}$ occurred from urea application through permanent flood in both years, but surface soil moisture content was much different.

In 2007, all $\mathrm{N}$ applications were made to very dry surface soils at both locations. These conditions were not conducive to urea-N volatilization or denitrification and response to $\mathrm{N}$ stabilizers would not necessarily be expected. There was no significant difference between untreated and treated urea with either Agrotain or Nutrisphere-N at location A. At location B, urea alone, urea treated with Agrotain and urea treated with Nutrisphere-N produced statistically equal yields.

In contrast, soil and environmental conditions were much more conducive to potential $\mathrm{N}$ loss in 2008 (Table 1). Wet surface soil conditions were found at both sites when urea-N was applied. This represents conditions much more conducive to potential urea-N volatilization loss. As a result, greater conversion of ammonium- $\mathrm{N}$ to nitrate- $\mathrm{N}$ would also be expected in 2008 as compared to 2007. Urea-N stabilization products such as Agrotain and Nutrisphere- $\mathrm{N}$ would be expected to have greater potential benefit under these conditions. In 2008, Agrotain provided statistically higher rice yields than untreated urea at $78 \mathrm{~kg} \mathrm{~N} \mathrm{ha}^{-1}$ for location A. Interestingly, Agrotain resulted in slightly higher yields than Nutrisphere at location A while Nutrisphere-N performed better than Agrotain at location B in 2008. 
David D. Dunn and Pawel Wiatrak / American Journal of Agricultural and Biological Sciences 9 (3): 401-406, 2014

Table 2. Effect of location, $\mathrm{N}$ rate and $\mathrm{N}$ additive on rice yields averaged for two years

\begin{tabular}{llr}
\hline $\mathrm{N}^{\text {Rate kg ha }}{ }^{-1}$ & N source & Rice Yield Mg ha $^{-1}$ \\
\hline 0 & Check & 6.5500 \\
78 & Urea & 8.3700 \\
118 & Urea & 9.0700 \\
157 & Urea & 9.3200 \\
78 & Urea + Agrotain & 8.6700 \\
118 & Urea + Agrotain & 9.0700 \\
157 & Urea + Agrotain & 9.3700 \\
78 & Urea + Nutrisphere-N & 8.5700 \\
118 & Urea + Nutrisphere-N & 8.9700 \\
157 & Urea + Nutrisphere-N & 9.1700 \\
& LSD $(0.10)$ & 0.8400 \\
& p>F & 0.0010 \\
& Main effects & $p>\mathrm{F}$ \\
& N Rate & $<0.001$ \\
& Additive & 0.5700 \\
& Location & $<0.001$ \\
& Year & $<0.001$ \\
& Interaction effects & $p>\mathrm{F}$ \\
& Additive x N Rate & 0.6700 \\
& N Rate x Year & 0.0400 \\
& Additive x Year & 0.0010 \\
& Additive x Location & 0.0900 \\
& Year x Location & $<0.001$ \\
& N Rate x Location & 0.8900 \\
& N Rate x Location x Year & 0.0100 \\
& Additive x Location x Year & 0.1700 \\
& Additive x N Rate x Year & 0.5800 \\
& Additive x N Rate x Location & 0.5000 \\
& Additive x N Rate x Location x Year & 0.8800 \\
\hline
\end{tabular}

Table 3. Effect of location, $\mathrm{N}$ rate and $\mathrm{N}$ additive on rice yields in 2007 and 2008

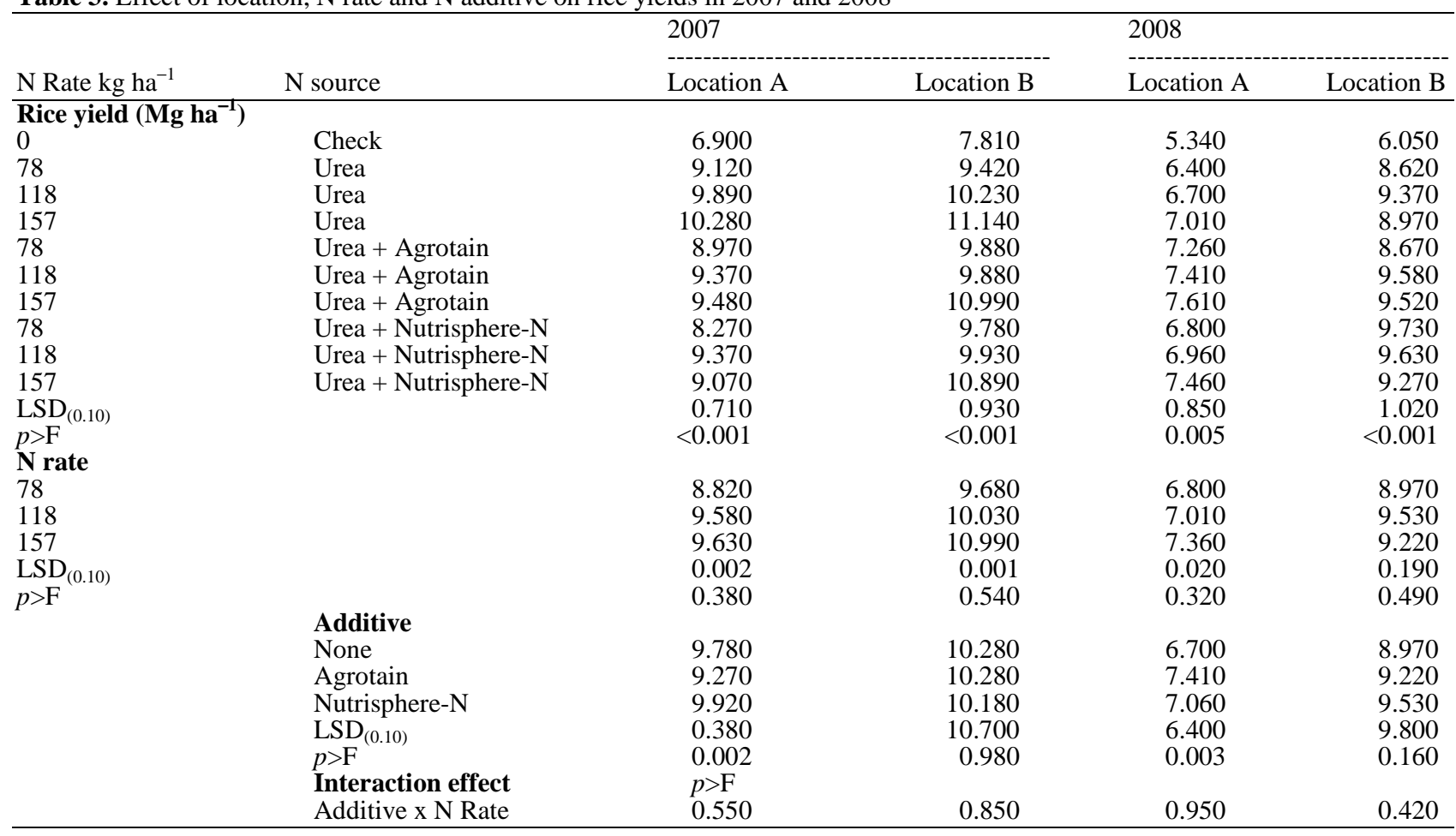




\section{DISCUSSION}

Our results highlight the fact that the potential benefit of using either Agrotain or Nutrisphere-N depends on the specific soil and environmental conditions at the time of urea application. Evaluations of these types of products need to be made in the context of conditions occurring for a particular field comparison and not simply combining studies with widely different soil and environmental conditions into a common database.

Differences in yields between locations are consistent with the yield potential of the soils at these two locations (Beighley et al., 2008; 2009). Likewise the overall effect of $\mathrm{N}$ rate on rice yields in our studies is well documented in the literature (Guindo et al., 1994; Norman et al., 1997; Stevens et al., 2008).

Leaching and denitrification are potential $\mathrm{N}$ loss pathways in crop production that affect only soil nitrate$\mathrm{N}$. Most $\mathrm{N}$ utilized by crops is as nitrate-N regardless of the form of $\mathrm{N}$ supplied to the crop, because of soil $\mathrm{N}$ reaction termed nitrification. Nitrification is the conversion of ammonium $\mathrm{N}$ to nitrate $\mathrm{N}$ by soil microbes in warm and aerated soils. Urea is not subject to nitrification until urea- $\mathrm{N}$ is transformed into ammonium$\mathrm{N}$ through urea hydrolysis.

Leaching is the downward movement of soluble nitrate-N through the crop root zone with water. Leaching is of most concern in coarse textured soils. Of more concern in rice production is denitrification, which is the conversion of plant available nitrate- $\mathrm{N}$ to plant unavailable $\mathrm{N}$ gases by anaerobic soil microbes in flooded or waterlogged soils. Ammonium-N is not subject to these losses until it is converted to nitrate-N by soil microbes (Harrison and Web, 2001).

Potential N losses via volatilization and denitrification in a direct seeded and delayed flood rice production system are clearly weather dependent. In a dry year these losses may be minimal. However, with the right rainfall pattern these losses can be significant. Urea hydrolysis (and subsequently potential urea-N volatilization loss) essentially stops when the soil surface is dry, but rapidly increases as the soil surface becomes moist. As a result, the potential for urea- $\mathrm{N}$ volatilization is greatest for urea application to wet soils. Sometimes scheduled pre-flood urea applications are delayed until the soil surface dries, but this is not always possible. While urea can be incorporated during rainfall, it generally takes $0.6 \mathrm{~cm}$ of precipitation or more to move urea below the soil surface. Lesser rainfall may serve to accelerate urea hydrolysis and increase the potential for urea-N volatilization.
Rice producers tend to view urea stabilizers as insurance against adverse weather conditions. The decision to purchase insurance ideally is based on the economic consequences of an unpredictable event being greater than the cost of the insurance. Since potential for urea-N volatilization and denitrification loss are highly weather dependent, there is a good measure of uncertainty concerning the potential for $\mathrm{N}$ loss at the time that management decisions need to be made. While a decision not to use stabilizers based on overall average for both years of this study might seem reasonable, better approach would be to evaluate conditions during critical time periods and then make a management decision based on existing conditions. In this case, surface soil moisture conditions and expected delay between urea-N application and establishment of permanent flood greatly affected the potential for $\mathrm{N}$ loss and as a result the potential benefit of including $\mathrm{N}$ stabilizers in the rice production program.

Therefore, rice producers can better evaluate the benefits of routinely using these $\mathrm{N}$ stabilizers with careful observation of soil conditions when $\mathrm{N}$ fertilizer is applied, weather forecasts and expected delays in the time between $\mathrm{N}$ application and permanent flood establishment. Another option might be for rice producers, who might decide to only include urea stabilizers as insurance protection for years when the potential for $\mathrm{N}$ loss is greatest. When wells and pumping capacity are mismatched with field size and it will take more than five days to establish permanent flood, the use of urea-N stabilizers is warranted.

\section{CONCLUSION}

This study investigated the response of rice to urea$\mathrm{N}$ stabilizers. It was designed and maintained to maximize the potential for these losses in this rice production system. The response varied depending on soil and environmental conditions present in 2007 and 2008. In 2007, very dry surface soil at the time of urea$\mathrm{N}$ application and the lack of rainfall through permanent flood establishment resulted in low potential for loss due to $\mathrm{N}$ volatilization. Consequently, no benefit of including either Agrotain or Nutrisphere with the urea application was measured. However, conditions for potential urea- $\mathrm{N}$ volatilization or denitrification were much more favorable in 2008 and rice yields increased with the use of Agrotain at $78 \mathrm{~kg}$ $\mathrm{N} \mathrm{ha}{ }^{-1}$ at location $\mathrm{A}$. On average the same year, Agrotain resulted in slightly higher yields than 
Nutrisphere at location A while Nutrisphere-N performed better than Agrotain at location B. Across years, Agrotain and Nutrisphere were similar in terms of slightly improving rice grain yields as compared to untreated urea at the rate of $78 \mathrm{~kg} \mathrm{~N} \mathrm{ha}^{-1}$.

\section{ACKNOWLEDGEMENT}

This author was funded by the gracious and continuing support of the Missouri Rice Research and Merchandising Council, Agrotain International and Specialty Fertilizer Products. Use of trade names is for the purposes of identification only and does not represent an endorsement by the University of Missouri.

\section{REFERENCES}

AI, 2012. Agrotain International.

Beighley, D., C. Dickens, R. Dickens, J. Dickens, K. Tindall et al., 2008. 2007 Missouri Rice Variety Performance Trials. In: Missouri Rice Research Update 2008, Beighley, D. and C. Dickens (Eds.)., Southeast MO State University, Special Rep. 0012008. pp: 19-24.

Beighley, D., C. Dickens, R. Dickens, J. Dickens, K. Tindall et al., 2009. 2008 Missouri Rice Variety Performance Trials. In: Missouri Rice Research Update 2009, Beighley, D. and C. Dickens (Eds.)., Southeast MO State University, Special Rep. 0012009, pp. 29-33.
Dunn, D. and G. Stevens, 2006. University of Missouri Soil Test Recommendations for Rice Production. In: Missouri Rice Research Update 2005, Dickens, C. and D. Beighley (Eds.)., Southeast MO State University, Special Rep. 001-2005, pp: 64-65.

Guindo, D., B.R. Wells and R.J. Norman, 1994. Cultivar and nitrogen rate influence on nitrogen uptake and partitioning in rice. Soil Sci. Soc. Am. J., 58: 840845 . 10.2136/sssaj1994.03615995005800030030x

Harrison, R. and J. Web, 2001. A review of the effect of $\mathrm{N}$ fertilizer type on gaseous emissions. Adv. Agron., 73: 65-108. DOI: 10.1016/S0065-2113(01)73005-2

He, Z., A. Alva, D. Calvert and D. Banks, 1999. Ammonia volatilization from different fertilizer sources and effects of temperature and soil $\mathrm{pH}$. Soil Sci., 164: 750-758.

Norman, R.J., C.E. Wilson, Jr., B.R. Wells, S. Ntamatungo and N.A. Slayton et al., 1997. Management of Agronomic Factors in Rice Production. In: Rice Research Studies, Norman, R.J. and T.H. Johnston, B.R. Wells (Eds.)., Ark. Agric. Exp. Stn. Res. Ser. pp: 169-177.

SASI, 1997. SAS/STAT: Procedures. Release 6.12. SAS Inst. Cary, NC. SASI Institute.

SFP, 2012. NutriSphere-N nitrogen fertilizer manager. SFP.

Stevens, G., A. Wrather, M. Rhine, E. Vories and D. Dunn. 2008. Predicting rice yield response to midseason nitrogen with plant area measurements. Agron. J., 100: 387-392. DOI: 10.2134/agrojnl2007.0261 